\title{
Interactions between Antibiotics and Human Neutrophils in the Killing of Staphylococci
}

\author{
STUDIES WITH NORMAL AND CYTOCHALASIN B-TREATED CELLS
}

\author{
Richard K. Root, Raul Isturiz, Abdolghader Molavi, Julia A. Metcalf, \\ and HARry L. MALECh, Department of Internal Medicine, Section of Infectious \\ Diseases, Yale University School of Medicine, New Haven, Connecticut 06510
}

\begin{abstract}
A B S T R A C T Normal and antibiotic-pretreated staphylococci were incubated with human neutrophils to determine the interactions between cells and antimicrobials in the killing of the organisms. Staphylococcus aureus 502A pretreated during log-phase growth with subinhibitory ( $1 / 4$ minimum inhibiting concentration) (MIC) concentrations of penicillin G were more susceptible to killing by normal neutrophils than untreated bacteria (intracellular survival $0.17 \pm 0.04$ vs. $1.5 \pm 0.38 \%$, mean $\pm S E M$, respectively, at $35 \mathrm{~min}$ in 14 experiments; $P<0.01$ by $t$ test). Furthermore, this enhanced susceptibility to killing was observed even when phagosome formation was inhibited by cytochalasin $B(65.6 \pm 4.6 \%$ pencillintreated vs. $30.5 \pm 4.5 \%$ untreated killed at $30 \mathrm{~min}$ in 14 experiments, $P<0.001$ ). Pretreatment of $S$. aureus with vancomycin similarly enhanced susceptibility to killing by cytochalasin B-treated polymorphonuclear leukocytes (PMN), whereas pretreatment with gentamicin did not.
\end{abstract}

The enchancement of killing by pretreatment with cell wall-active antibiotics was present in a doseresponse fashion to $1 / 16$ th the MIC. It required specific antimicrobial activity; i.e., penicillin activity was inhibited by penicillinase or by incubation with bacteria at $4^{\circ} \mathrm{C}$. It also required active cellular metabolism and intact neutrophils. For antibioticpretreated bacteria to be killed by normal and cytochalasin B-treated cells, phagocytosis or binding to the cells was essential via a serum opsonindependent mechanism. In experiments with the cytochalasin B-treated cells, all bound penicillin-treated bacteria were killed vs. only a fraction $(70 \%)$ of the bound untreated bacteria. Penicillin in 10 times the

Address reprint requests to Dr. Root.

Received for publication 17 March 1980 and in revised form 8 August 1980.
MIC had no direct effects on PMN phagocytic, metabolic, or microbicidal functions against a nonsusceptible organism, Candida albicans.

The results indicate a cooperative effect between cell wall-active antibiotics at low concentrations and human PMN in the killing of staphylococci. The model establishes conditions for the study of the mechanisms invoIved in the cooperation of these bactericidal systems.

\section{INTRODUCTION}

During the treatment of bacterial infection with antimicrobials, an important interaction must occur between the drug administered and the defenses of the host to eradicate the invading bacteria. Much has been learned about the action of antimicrobials on microorganisms $(1,2)$, and the mechanisms involved in the opsonization, phagocytosis, and killing of bacteria have been characterized to a great extent $(3,4)$. Relatively little is known, however, whether specific antimicrobials alter the encounter between phagocytes and bacteria by modifying the surface or other properties of the organisms.

With these points in mind the present investigations were undertaken. It was postulated that those compounds that modified the bacterial cell surface would be more likely to affect the processes of phagocytosis and killing by human granulocytes $(\mathrm{PMN})^{1}$ than any that have a subcellular locus of action. Since concentrations of antimicrobials that are subinhibitory with respect to growth and killing of bacteria may modify bacterial structure and physiology

\footnotetext{
1 Abbreviations used in this paper: DMSO, dimethyl sulfoxide; HBSS, Hanks' balanced salt solution; MIC, minimal inhibitory concentration; PMA, phorbol myristate acetate; PMN, polymorphonuclear leukocyte; TSB, trypticase soy broth.
} 
$(5,7)$, these were used to discriminate more clearly between effects of antibiotics and those of PMN on phagocytosis and killing. The results indicate that the susceptibility of staphylococci to killing by human PMN is significantly enhanced by pretreatment with antibiotics with a cell-wall, but not a ribosomal, site of action. Furthermore, susceptibility to killing is enhanced to the point that the organisms are killed without phagosome formation, that is, when bound to the surface of cytochalasin B-treated PMN.

\section{METHODS}

Reagents. Cytochalasin B was purchased from Aldrich Chemical Co., Inc., Milwaukee, Wisc., dissolved in dimethylsulfoxide (DMSO, Sigma Chemical Co., St. Louis, Mo.) to a concentration of $2.5 \mathrm{mg} / \mathrm{ml}$, and frozen at $-20^{\circ} \mathrm{C}$. Cytochalasin $B$ was used in the experimental suspensions at a final concentration of $5 \mu \mathrm{g} / \mathrm{ml}$, and fresh aliquots were thawed and used daily. ${ }^{14} \mathrm{C}$-labeled mixed L-amino acids, $\left[2-{ }^{14} \mathrm{C}\right]$ uracil, ${ }^{125} \mathrm{I}$, and Aquasol for liquid scintillation counting were purchased from the New England Nuclear Company, Boston, Mass. Trypticase soy agar and broth (TSB) were purchased from Baltimore Biological Laboratories, Cockeysville, Md. Lysostaphin was obtained from Schwartz/Mann, Div. Becton, Dickinson \& Co., Orangeburg, N. Y., and suspended in $0.9 \%$ saline at a concentration of $1,000 \mathrm{U} / \mathrm{ml}$. Hanks' balanced salt solution (HBSS) came from Flow Laboratories, Rockville, Md. 3\% dextran in saline, penicillinase, and cacodylate buffer were purchased from Sigma Chemical Co. Penicillin G was obtained from E. R. Squibb and Son, Inc., Princeton, N. J.; gentamicin from Schering Corp., Kenilworth, N. J.; and vancomycin from Eli Lilly \& Co., Indianapolis, Ind. $12 \times 75-\mathrm{mm}$ pyrex borosilicate tubes were purchased from Corning Glass Works, Corning, N. Y. Glutaraldehyde, Epon 812, and osmium tetraoxide were obtained from Electron Microscopy Sciences, Fort Washington, Pa. Phorbol myristate acetate was purchased from Consolidated Midland Co., Brewster, N. Y.

Microorganisms. The coagulase positive, penicillinase negative, Staphylococcus aureus H. R. Shinefield 502A (ATCC. 27217) was used in all experiments with bacteria. Using a previously described method (8), it was determined that this organism has a minimal inhibitory concentration (MIC) for penicillin $\mathrm{G}$ of $0.075 \mathrm{U} / \mathrm{ml}$, for gentamicin of 4.0 $\mu \mathrm{g} / \mathrm{ml}$, and for vancomycin of $0.25 \mu \mathrm{g} / \mathrm{ml}$. A strain of Candida albicans was kindly supplied by Dr. Vincent Andriole of Yale University School of Medicine for use in measurements of PMN candidacidal activity.

Serum. Normal human serum was obtained from the clotted blood of healthy consenting volunteers, pooled, separated into aliquots, and stored at $-70^{\circ} \mathrm{C}$ until used.

Leukocyte preparation. PMN were separated from the heparinized $(10 \mathrm{U} / \mathrm{ml})$ peripheral blood of healthy consenting volunteers. The blood was processed either by dextran sedimentation or by Ficoll-Hypaque and dextran sedimentation, with hypotonic lysis of the erythrocytes as previously described (9). The cells were washed in modified Hank's solution (9), centrifuged at $150 \mathrm{~g}$ for $7 \mathrm{~min}$ at $4^{\circ} \mathrm{C}$, enumerated by hemocytometer, and resuspended in antibiotic-free HBSS to a final concentration of $5 \times 10^{6} / \mathrm{ml}$. PMN comprised $80-95 \%$ of the final cell population and constituted $98 \%$ of the phagocytic cells.

Preparation of S. aureus. Samples taken from stock cultures (1/100 dilution) were incubated in fresh TSB at $37^{\circ} \mathrm{C}$ for $2 \mathrm{~h}$ to place the bacteria in the logarithmic phase of growth. At this point, the bacterial suspension was divided into two equal aliquots and the antibiotics to be tested were added to one (final concentrations $1 / 4$ to $1 / 32$ of the MIC), and sterile TSB to the other (control). Both bacterial suspensions were allowed to grow for another $2 \mathrm{~h}$. At the end of that period, the bacteria were removed from the antibiotic-containing broth by centrifugation at $2,200 \mathrm{~g}$ for $10 \mathrm{~min}$., washed by suspension in MHS, recentrifuged, and finally resuspended in HBSS. They were adjusted to $\sim 2.5 \times 10^{8} \mathrm{ml}$ after gentle sonication $(20,000 \mathrm{~Hz}$ output of $35 \mathrm{~W}$ for $15 \mathrm{~s}$, Bronson Sonic Power Co., Danbury, Conn.). The bacterial inoculum was standardized visually by turbidity. When desired, ${ }^{14} \mathrm{C}$ labeling of bacterial proteins was achieved by performing the 4 - $h$ incubation in the presence of $2-3 \mu \mathrm{Ci}\left(\sim 300,000\right.$ counts) of ${ }^{14} \mathrm{C}$-labeled mixed L-amino acids or $\left[{ }^{14} \mathrm{C}\right]$ uracil.

Bactericidal assays. $1-\mathrm{ml}$ suspensions containing $2.5 \times 10^{6}$ PMN and $2.5 \times 10^{7}$ bacteria were incubated in HBSS at $37^{\circ} \mathrm{C}$ in the presence of $10 \%$ serum as a source of opsonins. When cytochalasin B was used, the cells were preincubated with $5 \mu \mathrm{g} / \mathrm{ml}$ of the compound for $10 \mathrm{~min}$ at $37^{\circ} \mathrm{C}$ before the addition of the bacteria.

Initial samples ( 0 time) were taken immediately after addition of the bacteria to the tubes, which were then capped and rotated at $37^{\circ} \mathrm{C}$. Killing of the inoculum was measured at various times by a previously described method (10). In experiments with noncytochalasin B-treated cells, lysostaphin was added at the end of a $25-\mathrm{min}$ incubation period in a concentration of $10 \mathrm{U} / \mathrm{ml}$ for $10 \mathrm{~min}$ to kill extracellular bacteria. The percent survival was calculated by dividing the number of colony-forming units at various times by the number at $0 \mathrm{~min}$ and multiplying by 100 . From this figure the percent killing could be calculated by subtraction from 100 .

Phagocytosis assays. The association (binding plus phagocytosis) of viable ${ }^{14} \mathrm{C}$-labeled staphylococci with the cells was assessed as previously described $(9,11)$. Leukocytes in a final concentration of $2.5 \times 10^{6} / \mathrm{ml}$ were placed in $12 \times 75-\mathrm{mm}$ glass borosilicate tubes with HBSS and $10 \%$ serum for opsonization. After preincubation for $10 \mathrm{~min}$ at $37^{\circ} \mathrm{C}$, bacterial suspensions $\left(2.5 \times 10^{7}\right)$ were added to the mixture at 20 -s intervals. The capped tubes were allowed to rotate for $30-\mathrm{min}$, at which time phagocytosis was stopped by flooding the suspensions with $2 \mathrm{ml}$ of ice-cold HBSS containing $10 \%$ fetal calf serum and $0.2 \mathrm{M} \mathrm{NaF}$ and immediately placing them on ice. Preparation of the cell suspensions for radioactive counting was as previously described $(10,11)$. The percentage of organisms associated with the cells could be calculated by dividing cell-associated counts per minute by the counts per minute in the original inoculum and multiplying by 100 . Similarly the number of bacteria associated with the cells could be obtained from calculations of the specific activity of the radiolabeled organisms.

On several occasions, the bactericidal and phagocytosis assays were run simultaneously with the same inoculum. In experimental and control suspensions, the fraction of bacteria associated with the cells that were killed could thus be calculated. All the experiments were run in duplicate, as well as simultaneous cell-free controls.

Myeloperoxidase-mediated protein iodination. After incubation of bacteria with cells, the fixation of inorganic iodide to a trichloracetic acid-precipitable form was measured as previously described (12). The incubation conditions were similar to those in which the bactericidal assays were performed, containing $\sim 10$ bacteria/PMN and $10 \%$ serum in the medium.

Effect of penicillin $G$ on PMN functions. After the washing procedure, it did not seem likely that appreciable amounts of penicillin were carried over into the final incubation 


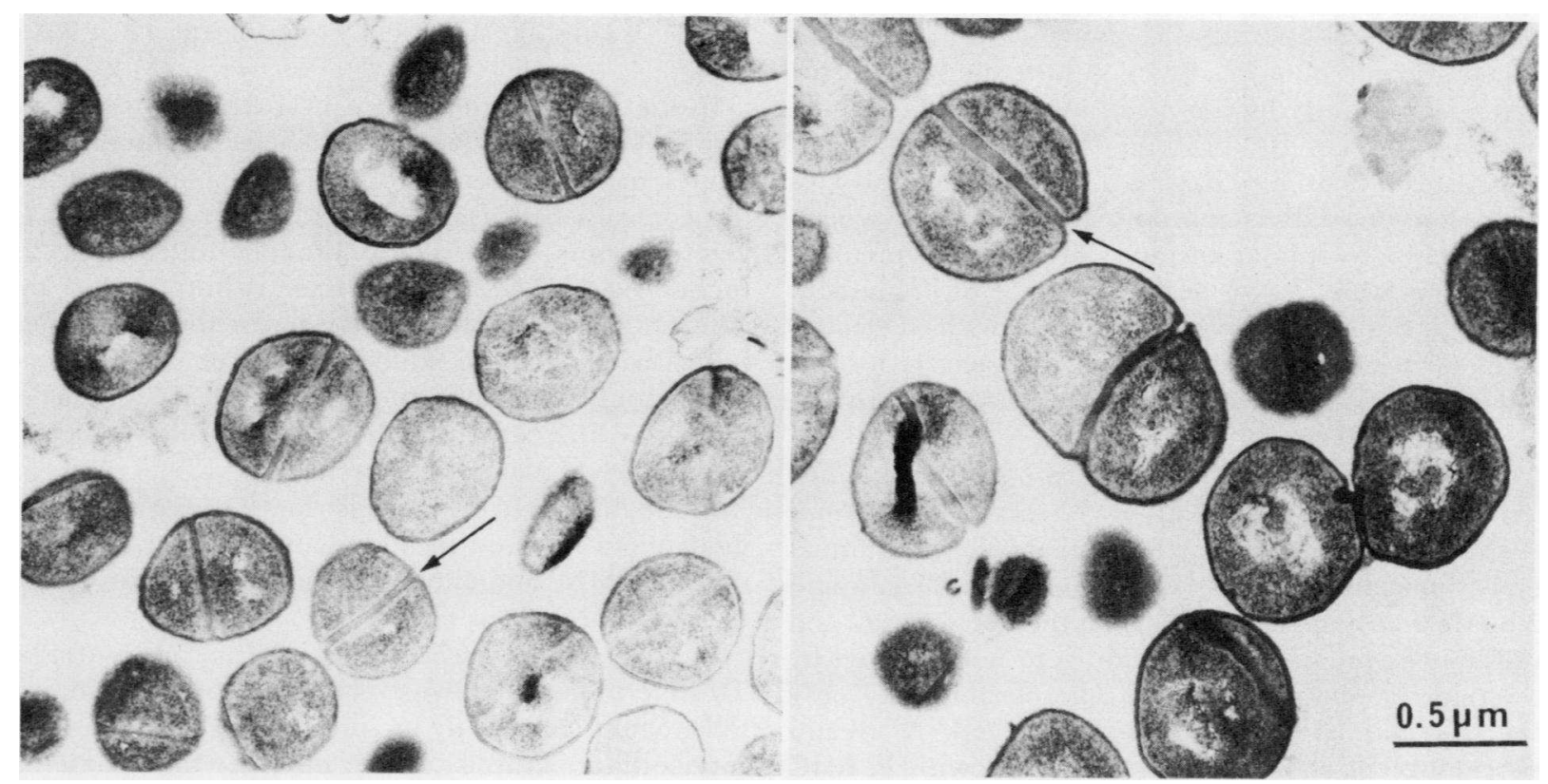

FIGURE 1 Transmission electron micrographs of log-phase $(2 \mathrm{~h}) \mathrm{S}$. aureus 502A grown either in TSB (left panel) alone or TSB to which $1 / 4$ MIC penicillin $G$ has been added. Arrows point to crosswalls. The magnification is $\times 28,000$.

mixtures. The concentrations used were subinhibitory not only for $S$. aureus, but for other highly susceptible microorganisms, and could not be detected in the final suspensions by a routine bioassay. ${ }^{2}$ Nevertheless, experiments were carried out to exclude any stimulatory effects of penicillin on PMN function independent of the action of the compound on the organisms. Phagocytosis of heat-killed S. aureus added to normal and cytochalasin B-treated PMN in a 10:1 ratio was measured in concentrations of penicillin up to 10 times the MIC $(0.75 \mathrm{U} / \mathrm{ml})$ by the methods described above. The release of $\mathrm{H}_{2} \mathrm{O}_{2}$ by normal and cytochalasin B-treated PMN ingesting opsonized $S$. aureus at a 500:1 bacteria-to-cell ratio in the presence and absence of $0.75 \mathrm{U} / \mathrm{ml}$ of penicillin was measured by a previously described method (11). Finally, the effect of adding the same concentration of penicillin on the killing of $C$. albicans by PMN was evaluated by a dyeexclusion technique (9), previously used in the laboratory.

Electron microscopy. Control or penicillin-pretreated staphylococci were incubated with normal or cytochalasin B-treated cells as outlined above. Bacteria-to-cell ratios of 5:1, 10:1, and 75:1 were used in different experiments, and the various suspensions were allowed to rotate at $37^{\circ} \mathrm{C}$ for $5,10,20,30$, and $60 \mathrm{~min}$. The PMN-bacteria interaction was terminated by mixing the suspension (at room temperature) with an equal volume of glutaraldehyde in $0.1 \mathrm{M}$ sodium cacodylate buffer at $\mathrm{pH} 7.4$; the mixture was immediately spun at $150 \mathrm{~g}$ for $7 \mathrm{~min}$. The supernate was removed and the pellet overlayed with additional glutaraldehyde buffer fixative for $15 \mathrm{~min}$. The pellet was then washed and stored in the sodium cacodylate buffer. Later, pellets were postfixed in $2 \%$ osmium tetraoxide in cacodylate buffer, stained for $1 \mathrm{~h}$ in $0.5 \%$ uranyl magnesium acetate in $0.15 \mathrm{M} \mathrm{NaCl}$, and then dehydrated in a graded

${ }^{2}$ Downs, J., K. P. Andriole, and V. T. Andriole. A modified agar gel diffusion bioassay procedure for the measurement of antibiotic concentrations in body fluids. Manuscript in preparation. series of ethanol washes and propylene oxide. The pellet was embedded in epon and cut with a diamond knife with an LKB I ultratome (LKB Instruments, Inc., Rockville, Md.). Sections were stained with uranyl acetate and lead citrate and examined in a Phillips 300 electron microscope (Phillips Electronic Instruments, Inc., Mahwah, N. J.).

Statistical analysis. The $t$ test or the sign test was used for analysis. Values of $P<0.05$ for differences between control and experimental preparations were considered statistically significant.

\section{RESULTS}

Effect of antibiotic pretreatment on bacterial growth and morphology. Incubation of organisms in the presence of $1 / 4$ MIC penicillin often reduced replication. The size of the viable bacterial population reached at the end of the 2 -h incubation period was usually $20-40 \%$ lower than it was in the antibiotic-free control and averaged $\sim 70 \%$ of the control for all experiments. By Petroff-Hausser chamber counting, the total numbers of organisms (viable and nonviable) were equal in both penicillin-treated and untreated preparations, and when washed free of penicillin, subsequent viability in suspensions incubated without PMN was equivalent. No growth inhibition occurred in the vancomycin- or gentamicin-treated populations.

Morphological differences between the penicillintreated bacteria and the control were observed as previously reported (13). The treated bacteria were larger, by phase-contrast and electron microscopy, and the cross walls of dividing organisms were thicker (Fig. 1). 
In the studies using ${ }^{14} \mathrm{C}$-amino acid labeling of bacteria, it was noted that penicillin-treated organisms had a significantly higher mean number of ${ }^{14} \mathrm{C}$ counts per minute per $10^{6}$ bacteria (82.5) than untreated organisms $(49.8, n=13, P<0.05)$, presumably reflecting reduced divisions of the treated staphylococci. Quantitatively similar results were found when the organisms were grown in the presence of $\left[{ }^{14} \mathrm{C}\right]$ uracil, although the labeling was higher than with ${ }^{14} \mathrm{C}$-amino acids (a mean 73.1 and $300 \mathrm{cpm} / 10^{6}$ bacteria for untreated and penicillin-treated organisms, respectively, $n=5, P<0.01$ ).

Effect of pretreatment with sub-MIC penicillin and gentamicin on killing of $S$. aureus by normal $P M N$. In preliminary bactericidal assays with normal cells, incubation periods varied between $35 \mathrm{~min}$ and $2 \mathrm{~h}$. Most killing occurred during the first $25 \mathrm{~min}$, and differences present at this time were not changed by a longer incubation. For the sake of simplicity only the 25- and 35-min data are presented. A greater percentage of staphylococci pretreated with $1 / 4$ MIC penicillin $G$ were killed at $25 \mathrm{~min}$ by normal PMN than untreated bacteria (Table I). Becuase of variability, the difference between the mean percent killing of the two populations is not statistically significant by $t$ testing; however, in 12 of the 14 experiments shown, more penicillin-treated bacteria were killed than controls. The likelihood that this would have occurred by chance alone is $<0.01$ (sign test). When intracellular survival $10 \mathrm{~min}$ after the addition of lysostaphin was examined, $\sim 6.7$ times more control bacteria were recovered than penicillintreated bacteria. The difference between the two

TABLE I

Killing of Untreated and Antibiotic-pretreated S. aureus 502A by Normal PMN*

\begin{tabular}{cccc}
\hline $\begin{array}{c}\text { Pretreatment } \\
\text { conditions }\end{array}$ & Inoculum & $\begin{array}{c}\text { Killed } \\
(25 \mathrm{~min})\end{array}$ & $\begin{array}{c}\text { Intracellular } \\
\text { survival } \\
(35 \mathrm{~min})\end{array}$ \\
\hline & No.bacteria & $\%$ & $\%$ \\
$\begin{array}{c}\text { No antibiotic } \\
(14)\end{array}$ & $11.7 \times 10^{6} \pm 1.7$ & $63.2 \pm 5.1$ & $1.14 \pm 0.21$ \\
$\begin{array}{c}\text { Penicillin } \\
1 / 4 \text { MIC (14) }\end{array}$ & $12.8 \times 10^{6} \pm 1.6$ & $72.4 \pm 4.8 \S$ & $0.17 \pm 0.4^{4}$ \\
$\begin{array}{c}\text { Gentamicin } \\
\text { 1/4 MIC (4) }\end{array}$ & $15.0 \times 10^{6} \pm 5.3$ & $63.3 \pm 8.8$ & $0.81 \pm 0.32$ \\
\hline
\end{tabular}

* The data are expressed as the mean $\pm S E M$ of the number of experiments shown in parentheses.

\$ The inoculum was equalized for viable bacteria in all experiments.

$\S P<0.01$, sign test, in comparison to simultaneously run controls.

" $P<0.01$, Student's $t$ test for paired samples in comparison with simultaneously run controls. means is highly statistically significant $(P<0.004$, $t$ test).

In the experiments shown in Table I, the suspensions of penicillin-pretreated bacteria actually contained more organisms (viable and nonviable) than the controls, because the inocula were equalized for viable counts. To exclude the possibility that the higher bacteria/cell ratio which resulted from this adjustment might augment killing by the PMN, heatkilled bacteria were added to control staphylococci in amounts sufficient to equalize the bacteria/cell ratios. No increase in killing of the control bacteria was observed (data not shown).

Pretreatment of $S$. aureus for $2 \mathrm{~h}$ with $1 / 4$ MIC gentamicin resulted in no enhancement of killing by normal PMN, and intracellular survival was similar to control organisms (Table I).

Dose-response effects of penicillin pretreatment. To determine the lowest concentration of penicillin that could be used in pretreatment to augment intracellular killing of $S$. aureus, the penicillin concentrations were serially decreased by twofold amounts. Pretreatment with as little as $1 / 16$ the MIC of penicillin augmented killing by normal PMN, but the effect was largely abolished at $1 / 32$ the MIC (Fig. 2).

Phagocytosis of control and penicillin-pretreated bacteria. To determine if the enhanced killing of penicillin-treated bacteria was due to increased rates of phagocytosis, the association of control and penicillin treated bacteria with the cells was studied by labeling the staphylococcal proteins with ${ }^{14} \mathrm{C}$-mixed amino acids as described in Methods. Uptake of normal and pretreated bacteria by the cells was equivalent (Fig. 3).

Effect of lysostaphin on control and penicillinpretreated bacteria. Penicillin treatment of grampositive cocci alters peptidoglycan structure and augments the susceptibility of the cell wall to attack by endogenous hydrolytic enzymes $(2,14)$. Lysostaphin is a mixture of hydrolases with peptidase, amidase, and glycosidase activities specific for the peptidoglycan of $S$. aureus (15). It thus seemed possible that its use in these experiments may have created a potential source of artifact, if small amounts were to enter the cells and affect the untreated and penicillin-pretreated intracellular organisms differentially. Accordingly, a dose-response assay was performed in the absence of PMN, comparing control and penicillin-treated $S$. aureus and using $1,0.1$, and $0.01 \mathrm{U} / \mathrm{ml}$ of lysostaphin $(10,100$, and 1,000fold less than that employed under standard incubation conditions with cells). $1 \mathrm{U} / \mathrm{ml}$ of lysostaphin killed both control and treated bacteria equivalently, whereas $0.01 \mathrm{U} / \mathrm{ml}$ was equally ineffective. A statistically significant increase in killing 


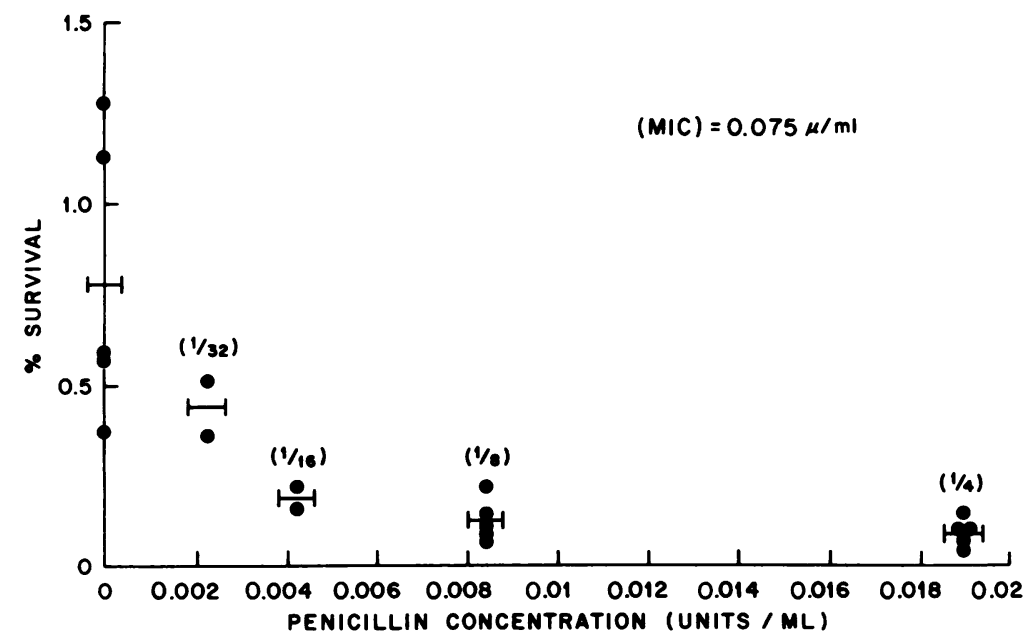

FIGURE 2 Relationship of penicillin concentrations in pretreatment to intracellular survival of $S$. aureus 502A in PMN. The results are expressed as the percentage of the original inoculum surviving $35 \mathrm{~min}$ after mixing bacteria with the PMN. The bars denote means, and the fractions of the MIC of penicillin used in pretreatment are shown in parentheses.

of $1 / 4$ MIC penicillin-treated S. aureus was observed when incubated for $10 \mathrm{~min}$ with $0.1 \mathrm{U} / \mathrm{ml}$ of lysostaphin (Fig. 4).

Studies with cytochalasin B-treated PMN: effect of penicillin pretreatment on bacterial killing. To avoid the use of lysostaphin and to determine if the susceptibility of penicillin-pretreated $S$. aureus to killing by PMN was sufficiently enhanced so that appreciable killing occurred even when phagosome formation was blocked, studies were performed with cytochalasin B-treated cells. Addition of cytochalasin $B$ to the PMN, as described in Methods, reduced the

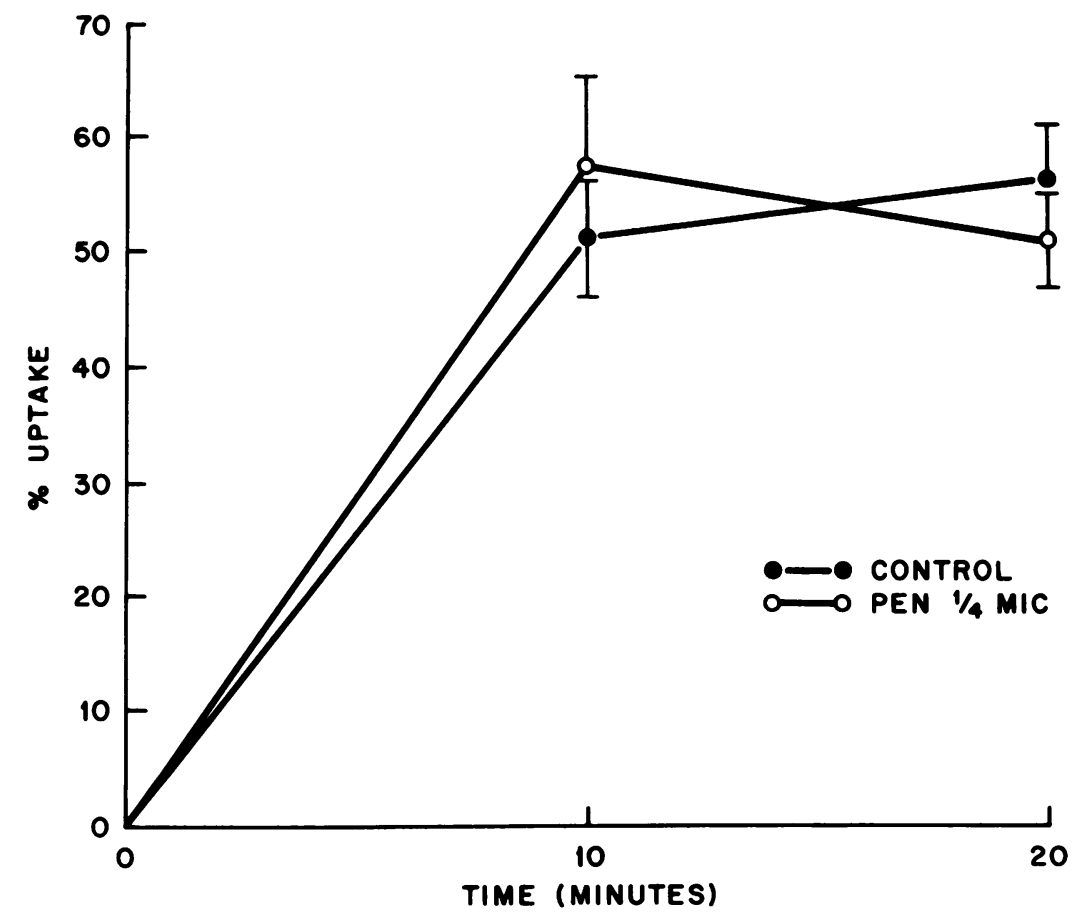

FIgURE 3 Phagocytosis of control (O) vs. 1/4 MIC penicillin-pretreated (O) S. aureus by normal $\mathrm{PMN}$. Results are given as mean $\pm \mathrm{SEM}$ of the percent cell association of control and pretreated $(1 / 4 \mathrm{MIC} \text { PCN })^{14} \mathrm{C}-\mathrm{S}$. aureus. 


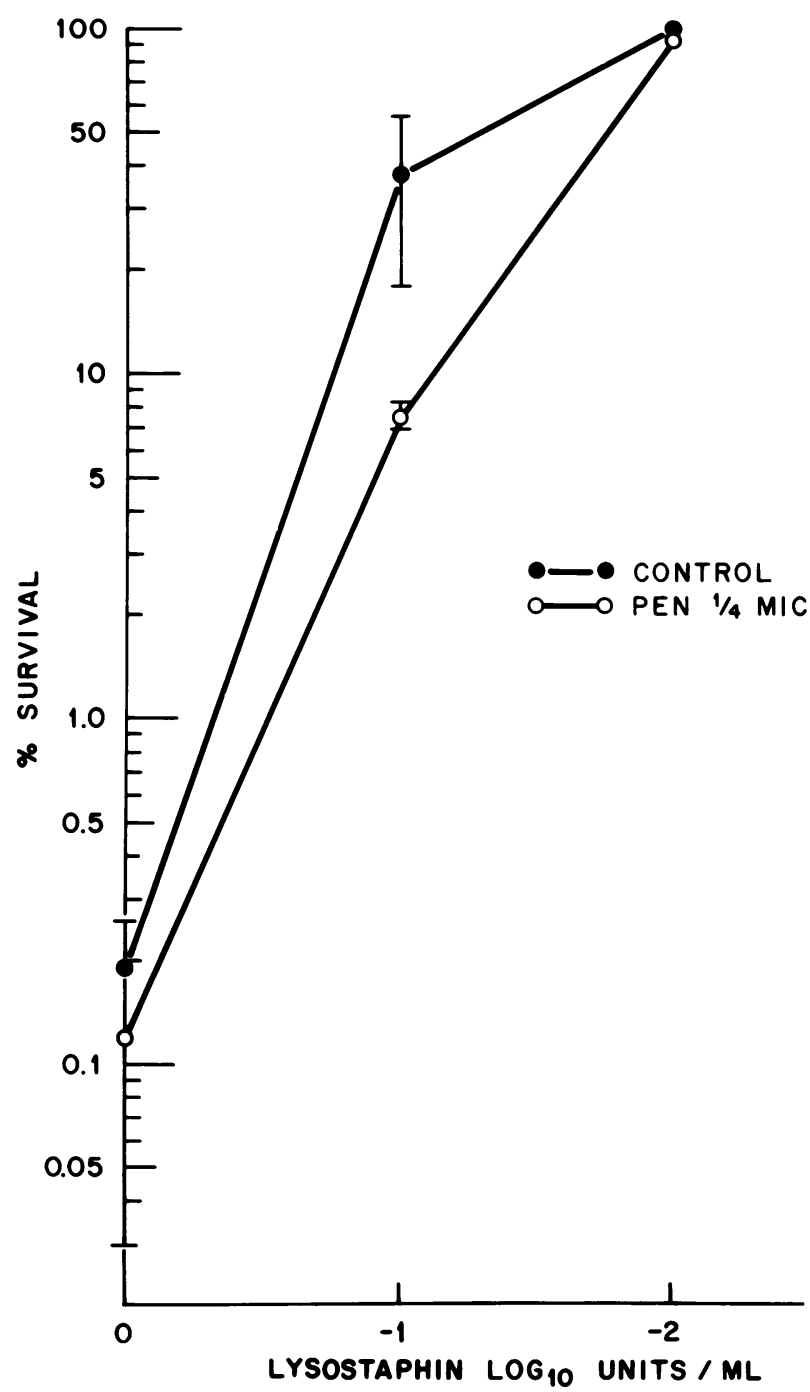

FIGURE 4 Survival of $S$. aureus 502A in the presence of 1.0, 0.1 , and $0.01 \mathrm{U} / \mathrm{ml}$ of lysostaphin at the conclusion of a 10-min incubation period. Brackets denote the range and circles the means of three experiments.

rates of killing of both normal and penicillin-treated $S$. aureus (Fig. 5). The percent reduction in killing of the penicillin-treated bacteria by cytochalasin B cells (a mean $26 \%$ at $30 \mathrm{~min}$ ) was significantly less than that of the control bacteria (a mean 67\%, P<0.01). In the presence of cytochalasin $B$, over twice as many penicillin-treated organisms as control were killed at $30 \mathrm{~min}$ (Table II). Similar results were found at $60 \mathrm{~min}$ incubation. Minimal, nonsignificant differences in survival of treated or nontreated bacteria occurred in the absence of cells, with or without cytochalasin B.

Effect of pretreatment of $S$. aureus with vancomycin or gentamicin on killing by cytochalasin Btreated cells. Vancomycin and gentamicin were used, separately, to determine if a cell wall-active

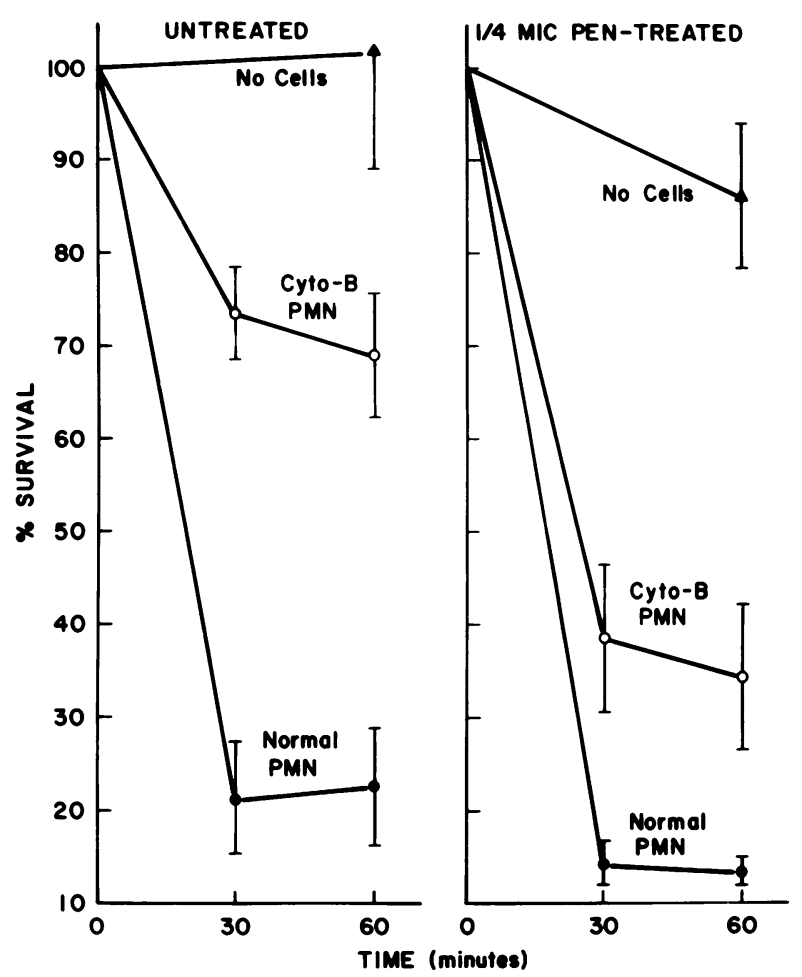

Figure 5 Effect of addition of cytochalasin B on the survival of untreated and Penicillin-pretreated $S$. aureus when incubated with PMN. Data are given as mean (circles) \pm SEM (brackets) percent survival in experiments of control and $1 / 4$ MIC penicillin-treated bacteria when incubated with normal (O) or cytochalasin B-treated (O) PMN. $n=4$.

antibiotic with a different site of action than penicillin or a ribosomally active compound had any effect on killing of $S$. aureus by PMN. Organisms were preincubated with $1 / 4$ MIC vancomycin or

TABLE II

Effect of Sub-MIC Antibiotic Pretreatment of S. aureus on Killing by Cytochalasin B-treated PMN*

\begin{tabular}{lcc}
\hline \multicolumn{1}{c}{ Pretreatment conditions } & \multicolumn{1}{c}{ Inoculum } & $\begin{array}{c}\text { Killed } \\
(30 \mathrm{~min})\end{array}$ \\
\hline & No. viable bacteria & $\%$ \\
No antibiotic (14) & $25.0 \times 10^{6} \pm 2.3$ & $29.3 \pm 4.9$ \\
Penicillin (1/4 MIC) (14) & $18.2 \times 10^{6} \pm 2.0 \ddagger$ & $62.8 \pm 2.7 \S$ \\
Vancomycin (1/4 MIC) (9) & $20.5 \times 10^{6} \pm 1.7$ & $51.1 \pm 2.8 \S$ \\
Gentamicin (1/4 MIC) (3) & $27.0 \times 10^{6} \pm 5.3$ & $12.6 \pm 5.3 \ddagger$ \\
\hline
\end{tabular}

* Results given are mean \pm SEM as follows. Data on inoculum are expressed as number of viable bacteria recovered after the pretreatment conditions shown on the left. Data on total killing indicate total percent killed at $30 \mathrm{~min}$. Numbers in parentheses represent number of experiments.

$\ddagger P<0.05$, Student's $\boldsymbol{t}$ test for paired samples in comparison with simultaneously run control untreated preparations. $\S P<0.01$, when compared with control untreated bacteria. 
gentamicin and the results of killing by cytochalasin B cells compared with penicillin-treated and control bacteria (Table II). As with penicillin, pretreatment with vancomycin enhanced susceptibility to killing, whereas gentamicin-pretreated organisms were killed less effectively than control.

Relationship of bacterial inoculum size to fraction killed. In these experiments with cytochalasin B PMN, the initial bacterial inoculum was not equalized for the number of viable organisms; thus, the number of viable bacteria incubated with the cells was significantly less for penicillin-pretreated than control organisms. To determine if such differences might affect the fraction of bacteria killed, bactericidal assays were performed in parallel with control and penicillin-pretreated $S$. aureus at different bacteriato-cell ratios. As noted by others (16), the fraction of bacteria killed remained essentially the same at bacteria/cell ratios ranging from $2.5 / 1$ to $10 / 1$ and significantly more penicillin-pretreated organisms were killed at each ratio (data not shown).

Dose-response relationship between vancomycin and penicillin pretreatment and enhanced killing by cytochalasin B-treated PMN. When the concentration of penicillin or vancomycin used in the preincubation was twofold serially reduced, a statistically significant increase in killing of the treated $S$. aureus was present in concentrations of the antimicrobials equal to $1 / 8$ the respective MIC (Table III), but killing continued to be greater to $1 / 16$ the MIC for the penicillin-pretreated bacteria.

In another series of experiments, the time of exposure of staphylococci to penicillin ( $1 / 4 \mathrm{MIC}$ ) was varied between $15 \mathrm{~min}$ and $4 \mathrm{~h}$. Enhancement of killing by exposure to this concentration of penicillin was observed with as little as $1 \mathrm{~h}$ pretreatment (data

TABLE III

Penicillin and Vancomycin Dose Response for Killing of S. aureus by Cytochalasin B-treated PMN*

\begin{tabular}{ccc}
\hline $\begin{array}{c}\text { Pretreatment } \\
\text { conditions }\end{array}$ & $\begin{array}{c}\text { Penicillin } \\
\text { (3) }\end{array}$ & $\begin{array}{c}\text { Vancomycin } \\
\text { (5) }\end{array}$ \\
\hline
\end{tabular}

$\%$ killed at $30 \mathrm{~min}$

$\begin{array}{lll}\text { No antibiotic } & 29.3 \pm 2.0 & 28.0 \pm 4.0 \\ 1 / 4 \text { MIC } & 70.2 \pm 5.9 \ddagger & 58.0 \pm 4.5 \ddagger \\ 1 / 8 \text { MIC } & 60.2 \pm 5.9 \ddagger & 53.0 \pm 4.0 \ddagger \\ 1 / 16 \text { MIC } & 45.3 \pm 5.2 & 32.0 \pm 15.7 \\ 1 / 32 \text { MIC } & 32.5 \pm 9.1 & 33.3 \pm 6.1\end{array}$

* Data are expressed as mean \pm SEM percent killing by cytochalasin B-cells of bacteria pretreated with penicillin and vancomycin at the MIC fractions shown on the left. The number of experiments are shown in parentheses.

$\ddagger P<0.05$ by paired $t$ testing in comparison with simultaneously run untreated controls. not shown). Exposure of organisms to penicillin for $>2 \mathrm{~h}$ did not significantly increase killing.

Requirement for specific activity of penicillin to enhance killing. To be certain that the penicillin effects were mediated by the specific action of the antibiotic on the bacteria, incubations were performed in the presence of penicillinase. No enhancement of killing occurred when penicillinase $(0.031 \mathrm{U})$ was added to the medium during the pretreatment phase with penicillin (a mean $36.6 \pm 5.6 \%$ killed at $30 \mathrm{~min}$ vs. $60.2 \pm 2.5 \%$, no penicillinase, $n=5, P<0.05, t$ test). Untreated bacteria were killed at equivalent rates with or without penicillinase (a mean 37.8 and $38.8 \%$, respectively).

Temperature dependence of penicillin and PMN effects. To determine if temperature-dependent steps were required for the action of the antibiotic on the bacteria as well as the cells on the organisms, the incubation conditions were varied: either the organisms were exposed to penicillin at $4^{\circ} \mathrm{C}$, or organisms pretreated in the usual fashion were incubated with cytochalasin B-treated cells at $4^{\circ} \mathrm{C}$. The penicillin effect was lost when the organisms were pretreated at $4^{\circ} \mathrm{C}$ and then incubated with cells at $37^{\circ} \mathrm{C}$. Similarly, when the bacteria were exposed to penicillin at $37^{\circ} \mathrm{C}$, but added to cells kept at $4^{\circ} \mathrm{C}$, a minimal reduction in the initial colony count occurred and no significant difference was observed in the killing of untreated and treated bacteria (Fig. 6).

Requirement for binding of bacteria to cytochalasin $B$-treated cells to promote killing. Staphylococci

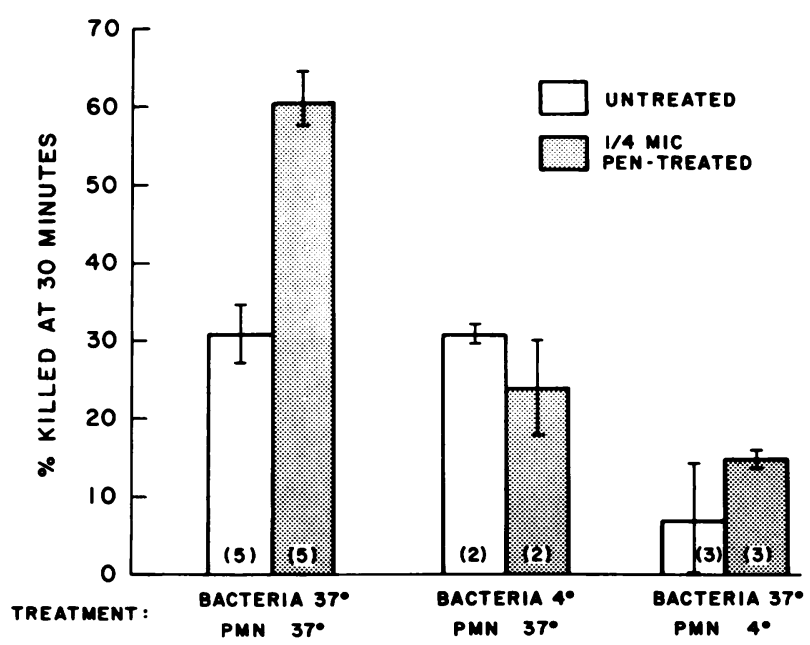

Figure 6 Temperature dependence of the augmented killing of penicillin-treated $S$. aureus by cytochalasin B-treated PMN. The temperature of incubation of the bacteria when pretreated with penicillin G ( $1 / 4 \mathrm{MIC})$ or with the PMN is shown on the abscissa. The bars are the means and the brackets the standard error of the number of experiments shown in parentheses. Killing was measured at $30 \mathrm{~min}$. 
pretreated with cell wall-active antibiotics were effectively killed by cytochalasin B PMN despite reduced phagocytosis (17); however, it was not clear from the experimental design whether killing was occurring in the suspending medium or if there was a requirement for intimate contact between the organisms and the cells. To answer this question, opsonizing serum was removed from the medium. No binding of ${ }^{14} \mathrm{C}$-tagged organisms to cytochalasin $\mathrm{B}$ treated cells took place in the absence of serum (data not shown); similarly no killing of either control or penicillin-treated bacteria occurred in serum-free suspensions (Fig. 7). Furthermore, when intact cells were destroyed by sonication, no killing occurred even in the presence of serum.

The need for this type of contact and its specificity for presumed opsonin receptors on the PMN surface were supported by two additional experiments. In one, bacteria and cells were incubated together in a pellet created by centrifuging the mixtures at $150 \mathrm{~g}$ for $5 \mathrm{~min}$. In the other, the cells were induced to release $\mathrm{O}_{2}^{-}$and $\mathrm{H}_{2} \mathrm{O}_{2}$, as well as to degranulate their specific granules into the incubation medium by the addition of PMA $(18,19)$. Killing did not occur in either set of conditions in the absence of opsonically active serum (Table IV).

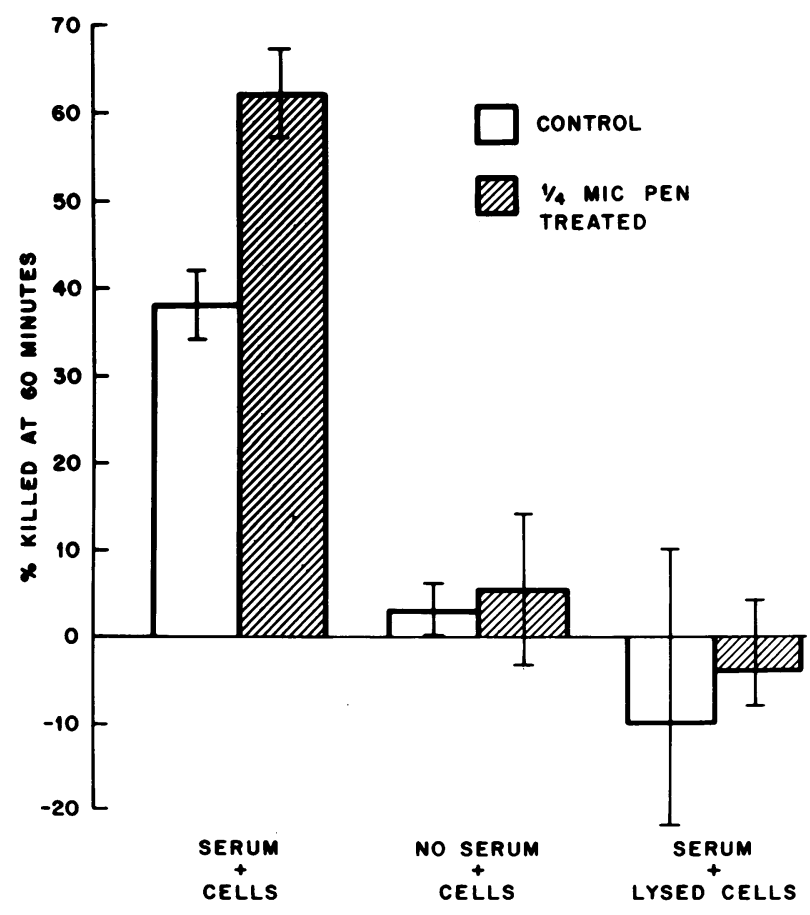

Figure 7 Killing of control and $1 / 4$ MIC penicillin-pretreated $S$. aureus $502 \mathrm{~A}$ at $60 \mathrm{~min}$ when incubated with PMN in $10 \%$ serum-HBSS (left bars), with PMN in HBSS alone (middle bars), or in $10 \%$ serum with cells lysed by sonication. The results represent the mean $\pm S E M$ of three experiments.

\section{TABLE IV}

Killing of Untreated and Penicillin-treated S. aureus by Cytochalasin B-treated PMN in the Absence of Serum: Effect of Phorbol Myristate Acetate or Incubation in a Pellet vs. Suspension*

\begin{tabular}{llcc}
\hline & & \multicolumn{2}{c}{ Percent killed } \\
\cline { 3 - 4 } $\begin{array}{l}\text { Incubation } \\
\text { conditions }\end{array}$ & \multicolumn{1}{c}{ Additions 1} & Untreated & $\begin{array}{c}\text { Penicillin- } \\
\text { treated }\end{array}$ \\
\hline Suspension $\$$ & None (4) & $-5.7 \pm 6.5$ & $-2.3 \pm 4.0$ \\
& 10\% serum (6) & $32.1 \pm 3.5$ & $56.5 \pm 5.0$ \\
& PMA (2) & $3.7 \pm 3.7$ & $3.1 \pm 3.1$ \\
& PMA plus 10\% & & \\
& serum (2) & $26.2 \pm 10.2$ & $50.1 \pm 3.7 "$ \\
& None (2) & $5.1 \pm 10.5$ & $8.2 \pm 14.3$ \\
& 10\% serum (2) & $17.9 \pm 2.4$ & $47.2 \pm 12.4 "$ \\
\hline
\end{tabular}

* Results are given as the mean \pm SEM percent bacteria killed at $30 \mathrm{~min}$ of the number of experiments shown in parentheses. \$ The suspending medium was HBSS, to which the serum (10\% final concentration) or PMA $(0.1 \mu \mathrm{g} / \mathrm{ml}$ final concentration) was added.

\$Suspension incubation conditions are the standard, whereas "pellet" incubation conditions are those created by centrifuging the bacteria and cells together for $5 \mathrm{~min}$ at $150 \mathrm{~g}$ (see Methods).

" $P<0.05$ when compared with untreated controls.

Relationship between binding of bacteria to the cells and killing. The experiments performed with and without serum suggested that killing by the cytochalasin B-treated cells required the close association or binding of intact PMN, presumably by receptors for opsonins on the bacterial surface (20). A slight modification of the bactericidal and phagocytic assays (as described in Methods) permitted the simultaneous evaluation of both association of bacteria with the cells and killing in order to calculate the fraction of "bound" organisms that were killed.

Using this technique, the mean percent "binding" of normal and penicillin-pretreated bacteria to the cells was equivalent and ranged from 40 to $50 \%$.

When killing was analyzed, $\sim 70 \%$ of bound, untreated bacteria labeled with ${ }^{14} \mathrm{C}$-amino acids were killed, whereas virtually all bound, penicillin-treated organisms were killed $(P<0.01)$ (Fig. 8).

When similar studies were carried out with $\left[{ }^{14} \mathrm{C}\right]$ uracillabeled bacteria the percentage of added penicillintreated bacteria associated with the cells at $30 \mathrm{~min}$ was calculated to be slightly higher $(53.2 \pm 2.7 \%)$ than for ${ }^{14} \mathrm{C}$-amino acid-labeled organisms $(45.9 \pm 3.3 \%, n=5$, $P<0.1, t$ test). The fraction of cell-associated $\left[{ }^{14} \mathrm{C}\right]$ uracillabeled organisms that were killed remained significantly higher after penicillin pretreatment $(92.6 \pm 5.3 \%)$ than when the organisms were untreated $(46.9 \pm 7.1 \%$, $n=5, P<0.01, t$ test $)$. 


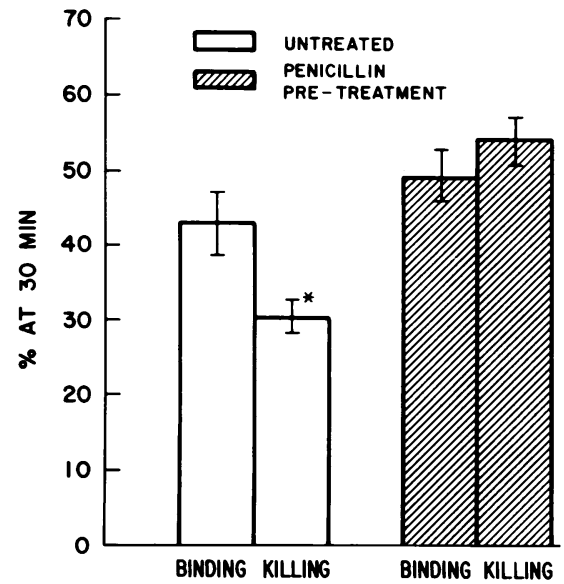

FIGURE 8 Relationship between the cell association ("binding") and killing at $30 \mathrm{~min}$ of $S$. aureus $502 \mathrm{~A}$ by cytochalasin B-treated PMN after growth of bacteria for $2 \mathrm{~h}$ in TSB alone or in TSB containing $1 / 4$ MIC penicillin. The results are the mean \pm SEM of eight experiments. "Binding" was measured using bacteria labeled with ${ }^{14} \mathrm{C}$-amino acids (see Methods). $P<0.05$.

Stimulation of PMN-myeloperoxidase-mediated protein iodination. The rate of bacterial killing by PMN parallels the rate of phagocytosis, as does the metabolic activity of the cells $(3,11,12,16,17)$. Having demonstrated that the rates of phagocytosis (for normal PMN) and binding (for cytochalasin B cells) were not affected by penicillin pretreatment of the bacteria, we measured the stimulation of myeloperoxidase- $\mathrm{H}_{2} \mathrm{O}_{2}$-mediated protein iodination by the cells. No difference in the quantity of iodide fixed to protein was found in PMN incubated in $10 \%$ serum-HBSS with normal vs. penicillintreated bacteria $(0.138 \pm 0.09$ vs. $0.159 \pm 0.01 \mathrm{nmol} / 2.5$ $\times 10^{6} \mathrm{PMN}$ per $30 \mathrm{~min}$, respectively, mean $\pm \mathrm{SEM}$ of three experiments).

Lack of direct effects of penicillin on PMN functions. The addition of up to 10 times the MIC $(0.75$ $\mathrm{U} / \mathrm{ml}$ ) of penicillin to the medium did not alter the phagocytosis of heat-killed $S$. aureus by normal (6.35 vs. $63.8 \%)$ or cytochalasin B-treated cells (39.3 vs. $35.6 \%$ uptake at $30 \mathrm{~min}$ in the absence and presence of penicillin, respectively, $n=2$ ). Similar concentrations of penicillin did not affect the rate of $\mathrm{H}_{2} \mathrm{O}_{2}$ released during ingestion of $S$. aureus by normal or cytochalasin Btreated cells, nor the percentage of $C$. albicans killed after a 60 -min incubation ( 29.0 vs. $29.3 \%$, no penicillin vs. penicillin in the medium, respectively, $n=1$ ).

Ultrastructural features of bacteria incubated with cells. Killing of staphylococci by penicillin can be associated with lysis of the organisms $(1,2)$. To see if morphological changes consistent with lysis occurred in bacteria incubated with the cytochalasin B PMN, transmission electron micrographs of suspensions in- cubated from 5 to $60 \mathrm{~min}$ were compared. Beyond the initial structural changes induced by penicillin, no differences were observed between control and penicillin-treated bacteria to suggest earlier lysis of the latter. Indeed, little evidence of lysis of cell walls in either preparation was observed through $30 \mathrm{~min}$ incubation (Fig. 9).

\section{DISCUSSION}

Several reports have appeared describing the interaction of antimicrobials with leukocytes in the killing of bacteria. Gentamicin $(21,22)$ and several tetracyclines (23) may inhibit chemotactic responses of PMN, but their ability to modify phagocytosis and killing has not been reported. Intracellular staphylococci are protected from the action of $\beta$-lactams, vancomycin, aminoglycosides, and a variety of other antimicrobials except rifampin (24). This has formed the basis of assays of leukocyte bactericidal activity, in which extracellular organisms are selectively killed by addition of antibiotics (25). In one such study it was observed that addition of penicillin in MIC or greater concentrations to susceptible organisms before incubation with PMN augmented the killing process (26). From this experimental design, however, it was difficult to distinguish between any separate effects of the antibiotics vs. the PMN on the bacteria. When initiating our studies, we were stimulated by a report that pretreatment of staphylococci with nafcillin accelerated their subsequent phagocytosis by mouse macrophages (27) and that the use of sub-MIC penicillin increased the susceptibility of staphylococci to killing by mixtures of lysozyme and trypsin (28) or to lysosomal extracts (29).

We chose to pretreat the staphylococci with concentrations of the antibiotics that were subinhibitory with respect to growth and viability. This choice was based upon two observations: (a) sub-MIC antibiotics may produce measureable morphological changes in bacteria in vitro without importantly affecting viability $(13,30)$; and $(b)$ such concentrations and morphological alterations may be found at tissue sites of infection in vivo $(31,32)$.

When organisms are treated with subinhibitory concentrations of antibiotics, the primary action of which is to inhibit protein synthesis, the rate of division is slowed and preceeded by a prolonged lag phase (33, $34)$. Abnormally thick walls may be observed with some bacteria, including staphylococci $(6,13)$. The $\beta$-lactams and other cell wall-active antibiotics produce two major effects on susceptible organisms in sub-MIC concentrations. One is to impede crosswall formation so that unusually long filamentous cells are formed (6); the other is to cause the formation of thickened cross walls without subsequent separation (13). The latter changes 

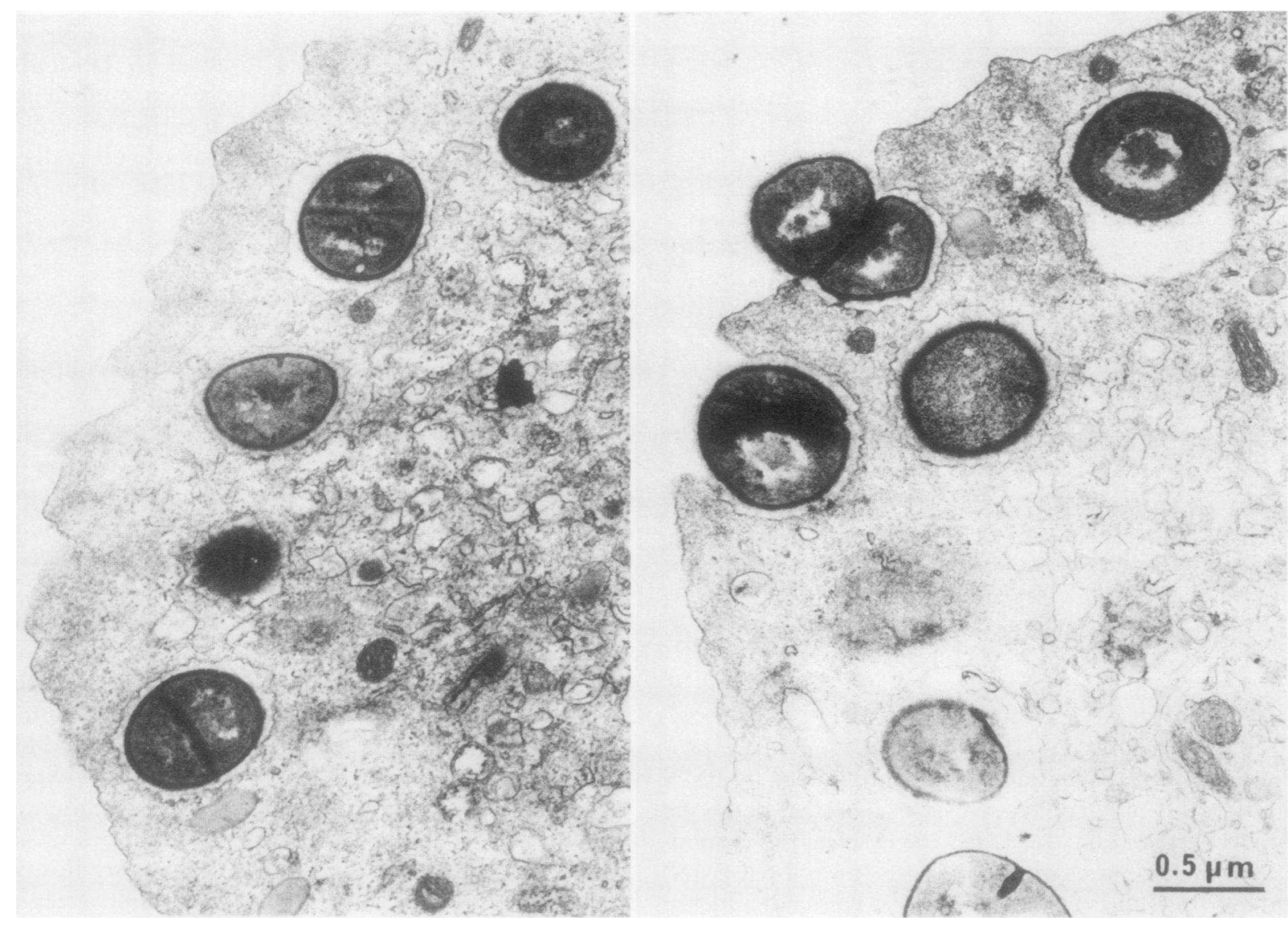

FIGURE 9 Transmission electron micrographs of cytochalasin B-treated PMN incubated for 30 min with untreated (left panel) and $1 / 4$ MIC penicillin-treated (right panel) S. aureus. Magnification is $\times 28,000$. The bacteria/cell ratio was $75 / 1$.

are particularly characteristic of staphylococci exposed to subinhibitory concentrations of the penicillins and were seen after $2 \mathrm{~h}$ incubation of $S$. aureus $502 \mathrm{~A}$ with $1 / 4$ MIC penicillin $G$ in the present studies. When incubation of staphylococci with sub-MIC penicillins is prolonged, then very large multiseptate organisms have been described (13), a morphologic feature not observed with our incubation conditions.

As drug concentrations approach the MIC, a progressive loss of viability (i.e., ability to replicate) has been observed (30). In our studies, use of $1 / 4$ MIC penicillin $\mathrm{G}$ for most experiments resulted in an average $30 \%$ inhibition of growth, although in some experiments growth over a 2 -h period was equal to untreated controls. The decreased number of cell divisions in the presence of penicillin was reflected by a greater accumulation of ${ }^{14} \mathrm{C}$-amino acids and $\left[{ }^{14} \mathrm{C}\right]$ uracil per organism when specific activities were calculated. When the organisms were removed from the antibiotic or when penicillinase was added, no further inhibition of growth was noted. This is consistent with the reversible nature of penicillin effects on cell wall synthesis at these low concentrations, as reported by others $(2,6)$. Although not measured in our studies, exposure of the staphylococci to low concentrations of the cell wallactive drugs might be expected to cause release of some bacterial surface macromolecules $(2,35)$. Similar data are not available for the aminoglycosides, represented in our studies by gentamicin.

By pretreating staphylococci with the antibiotics before exposing them to the PMN, we were able to distinguish between effects of the antibiotics on the bacteria and effects of the PMN on control and treated organisms. The results indicate that when cell wall-active drugs are employed in the pretreatment period, the susceptibility of $S$. aureus $502 \mathrm{~A}$ to killing by PMN is appreciably enhanced. Normal PMN killed $\sim 10 \%$ more bacteria over a relatively brief, but definitive incubation period; almost sevenfold fewer intracellular penicillin-pretreated organisms were recovered from normal PMN when lysostaphin was added to the medium. The enhanced killing was not a function of increased rates of phagocytosis.

The mixture of cell wall lytic enzymes in lysostaphin 
$(15,36)$ proved to be more active in killing penicillinpretreated than untreated $S$. aureus at low concentrations $(0.1 \mathrm{U} / \mathrm{ml})$, this posed the possibility of artifact in the measurement of intracellular survival of organisms after the addition of lysostaphin to the medium. To avoid the use of lysostaphin and to determine if susceptibility to killing by pretreatment with cell wallactive antibiotics was so enhanced that it could be observed even when phagosome formation was inhibited, experiments were conducted using cytochalasin B. Cytochalasin B is known to retard the ingestion phase of phagocytosis while permitting the binding of organisms to the cell surface $(17,37,38)$. In the presence of cytochalasin $\mathrm{B}$, the uptake of opsonized ${ }^{14} \mathrm{C}-\mathrm{S}$. aureus by PMN was inhibited by $\sim 40 \%$, a finding similar to our previously published studies (17). Killing of untreated S. aureus was inhibited even more strikingly $(>65 \%)$ in the presence of cytochalasin B, a finding noted by others $(37,38)$. In contrast, cytochalasin Btreated PMN killed penicillin-pretreated S. aureus surprisingly well, with the net result that over twice as many pretreated as untreated S. aureus were killed by PMN in the presence of cytochalasin B. When another cell wall-active antibiotic, vancomycin, with a different mode of action (39), was used for pretreatment, similar results were found. Treatment of organisms with sub-MIC gentamicin, an antibiotic without known ability to modify the bacterial cell surface (40), not only had no enhancing effect on killing by cytochalasin B-exposed PMN, but actually inhibited it, for reasons that remain unclear.

Conditions for the enhancement of killing by pretreatment with cell wall-active antibiotics were established. As little as $1 / 8$ MIC of penicillin or vancomycin were active and at least $1 \mathrm{~h}$ of contact between antibiotics and bacteria was necessary. The intact $\beta$-lactam ring of penicillin was required, since the effect was reversed by the addition of penicillinase during pretreatment. Both penicillin action on the organisms and the action of the PMN on the pretreated bacteria involved temperature-dependent steps, thus implying that metabolic energy is essential both for the antibiotic and leukocyte activities. Furthermore, killing was not observed with sonicates of cells, suggesting that the bactericidal event was triggered only by a specific contact between the organisms and intact PMN.

In studies to define the nature of this contact, it was determined that organisms could not be killed when simply mixed with the cells, even when close contact was established by cocentrifugation of bacteria and cells, or when $\mathrm{O}_{2}^{-}, \mathrm{H}_{2} \mathrm{O}_{2}$, and specific lysosomal granule discharge were provided by the addition of PMA (18, 19). Opsonizing serum was essential to promote the killing effect under all conditions examined, indicating that the organisms had to bind to opsonin receptors (20) on the cells or be ingested to trigger the bactericidal response. When simultaneous studies of bacterial cell association and killing were carried out using radioactive labels of bacterial proteins or nucleic acids, it was determined that penicillin (and presumably vancomycin) acted by increasing the susceptibility of staphylococci to leukocyte bactericidal mechanisms, rather than by improving opsonization or the uptake of bacteria by the cells. In fact, the data indicate that virtually all cell-associated, penicillin-pretreated staphylococci were killed by cytochalasin B PMN compared with only a fraction of those not pretreated.

The increased killing of penicillin-treated bacteria was not due to enhanced cellular responses as measured by myeloperoxidase- $\mathrm{H}_{2} \mathrm{O}_{2}$-mediated protein iodination. Furthermore, incubation of the PMN in up to 10 times the amount of penicillin used for pretreatment of bacteria did not nonspecifically increase PMN phagocytic or metabolic activities, alter the PMN responses to cytochalasin $\mathrm{B}$, or promote killing of a nonpenicillin-susceptible organism, C. albicans.

The precise mechanism(s) by which pretreatment of staphylococci with cell wall-active antibiotics augments their susceptibility to killing by PMN remains to be determined. The antibiotic and PMN effects could be independent (affecting differing loci) or interdependent and perhaps sequential in their action. Transmission electron microscopy showed little evidence of lysis of either the control or penicillin-treated staphylococci after 60 min incubation (a time at which most of the bacteria were dead). Thus, a lytic killing mechanism by the PMN similar to that of penicillin seems unlikely. The fact that antibiotic enhancement of killing was not reproduced by a drug that acts at the level of the bacterial ribosome, suggests that surface characteristics of organisms are important in regulating susceptibility to killing by PMN.

We have subsequently obtained evidence that modification of the surface of staphylococci by pretreatment with cell wall-active antibiotics increases their susceptibility to the nonoxidative as opposed to the oxidative killing mechanisms of PMN $(4,41)$. Furthermore, these observations have now been extended to other pathogenic strains of staphylococci (including those that produce $\beta$-lactamase), other antimicrobial compounds with a similar mechanism of action (42) and to pneumococci and other streptococci (43). Finally, the lytic arm of complement does not appear to participate in the enhanced killing of penicillin-pretreated S. aureus (44). Detailed reports of these findings are being prepared.

In conclusion, we have demonstrated a cooperative effect between the antimicrobial properties of PMN and those of two antibiotics which modify bacterial cell surface structure by different mechanisms. The susceptibility of staphylococci to killing was enhanced by pretreatment with sub-MIC doses of cell wall-active 
antibiotics to where it readily occurred in the absence of complete phagosome formation by the PMN. Although the relevance of these observations to clinical situations remains to be established, the model we have described provides a means to examine the occurrence and mechanism of similar interactions between a wide variety of antibiotics and microorganisms.

\section{REFERENCES}

1. Kucers, A., and N. McK. Bennett. 1979. The Use of Antibiotics. J. B. Lippincott Co., Philadelphia, Pa. 3rd edition.

2. Tomasz, A. 1979. The mechanism of the irreversible antimicrobial effect of penicillins: how the beta-lactam antibiotics kill and lyse bacteria. Ann. Rev. Microbiol. 33: 113-137.

3. Silverstein, S. C., R. M. Steinman, and Z. A. Cohn. 1977. Endocytosis. Ann. Rev. Biochem. 46: 669-722.

4. Klebanoff, S. M. 1975. Antimicrobial systems in neutrophilic polymorphonuclear leucocytes. Semin. Hematol. 12: $117-142$.

5. Gardner, A. D. 1940. Morphological effects of penicillin on bacteria. Nature (Lond.). 146: 837-838.

6. Lorian, V., and B. Atkinson. 1976. Effects of subinhibitory concentrations of antibiotics on cross walls of cocci. Antimicrob. Agents Chemother. 9: 1043-1055.

7. Lorian, V., M. Koike, O. Zak, U. Zanon, G. G. Grassi, and L. D. Sabath. 1978. Effects of subinhibitory concentrations of antibiotics on bacteria. Curr. Chemother. 1: $72-78$.

8. Washington, J. A., and A. L. Barry. 1974. Dilution test procedures. E. H. Lenaette, E. H. Spaulding, and J. P. Truant, editor. In Manual of Clinical Microbiology. American Society of Microbiology, Washington, D. C. 2nd edition. 410-417.

9. Root, R. K., A. S. Rosenthal, and D. J. Balestra. 1972. Abnormal bactericidal, metabolic, and lysosomal functions of Chediak-Higashi syndrome leukocytes. J. Clin. Invest. 51: 649-665.

10. Harris, M. B., I. Djerassi, E. Schwartz, and R. K. Root. 1974. Polymorphonuclear leukocytes prepared by continuous flow filtration leukopheresis: viability and function. Blood. 44: 707-713.

11. Root, R. K., J. Metcalf, N. Oshino, and B. Chance. 1975. $\mathrm{H}_{2} \mathrm{O}_{2}$ release from human granulocytes during phagocytosis. I. Documentation, quantitation, and some regulating factors. J. Clin. Invest. 55: 945-955.

12. Root, R. K., and T. P. Stossel. 1974. Myeloperoxidasemediated iodination of granulocytes. J. Clin. Invest. 53: $1207-1215$.

13. Lorian, B. 1975. Some effects of subinhibitory concentrations of penicillin on the structure and division of staphylococci. Antimicrob. Agents Chemother. 7: 864-870.

14. Rogers, H. J. 1967. Killing of staphylococci by penicillins. Nature (Lond.). 213: 31-33.

15. Schaffner, W., M. Melley, J. Hash, and M. Koenig. 1966. Lysostaphin: an enzymatic approach to staphylococcal disease. Yale J. Biol. Med. 39: 215-229.

16. Leijh, P. C. J., M. T. Van den Barselaar, T. L. van Zwet, I. Dubbeldman-Rempt, and R. Van Furth. 1979. Kinetics of phagocytosis of Staphylococcus aureus and Escherichia coli by human granulocytes. Immunology. 37: 453-465.

17. Root, R. K., and J. A. Metcalf. 1977. $\mathrm{H}_{2} \mathrm{O}_{2}$ release from human granulocytes during phagocytosis: relationship to superoxide anion formation and cellular catabolism of
$\mathrm{H}_{2} \mathrm{O}_{2}$ : studies with normal and cytochalasin B-treated cells. J. Clin. Invest. 60: 1266-1279.

18. Root, R. K., H. L. Malech, and J. A. Metcalf. 1978. Plasma membrane role in superoxide $\left(\mathrm{O}_{2}^{\bar{C}}\right)$ and $\mathrm{H}_{2} \mathrm{O}_{2}$ formation by human neutrophils. Clin. Res. 26: 355A.

19. Repine, J. E., J. G. White, C. C. Clawson, and B. M. Holmes. 1974. Effects of phorbol myristate acetate on the metabolism and ultrastructure of neutrophils in chronic granulomatous disease. J. Clin. Invest. 54: 83-90.

20. Verhoef, J., P. K. Peterson, and P. G. Quie. 1977. Human polymorphonuclear leukocyte receptors for staphylococcal opsonins. Immunology. 33: 231-239.

21. Khan, A. J., H. E. Evans, L. Glass, P. Khan, C. T. Chang, and C. R. Nair. 1979. Abnormal neutrophil chemotaxis and random migration induced by aminoglycoside antibiotics. J. Lab. Clin. Med. 93: 295-300.

22. Seklecki, M. A., R. Quintilliani, and E. G. Maderazo. 1978. Aminoglycoside antibiotics moderately impair granulocyte function. Antimicrob. Agents Chemother. 13: 552-554.

23. Russel, M. R., G. A. Warr, R. B. Couch, H. Yeager, and V. Knight. 1974. Effects of tetracycline on leucotaxis. J. Infect. Dis. 129: 110-116.

24. Mandell, G. L. 1973. Interaction of intraleucocytic bacteria and antibiotics. J. Clin. Invest. 52: 1673-1679.

25. Alexander, J. W., D. B. Windhorst, and R. A. Good. 1968. Improved test for the evaluation of neutrophil function in human disease. J. Lab. Clin. Med. 72: 136-148.

26. Alexander, J. W., and R. A. Good. 1968. Effect of antibiotics on the bactericidal activity of human leukocytes. J. Lab. Clin. Med. 71: 971-983.

27. Friedman, H., and G. H. Warren. 1974. Enhanced susceptibility of penicillin-resistant staphylococci to phagocytosis after in vitro incubation with low doses of nafcillin. Proc. Soc. Exp. Biol. Med. 146: 707-711.

28. Warren, G. H. and J. Gray. 1967. Influence of nafcillin on enzymic lysis of Staphylococcus aureus. Can.J. Microbiol. 13: 321-328.

29. Efrati, C., T. Sacks, N. Neleman, M. Lakov, and I. Ginsburg. 1976. The effect of leukocyte hydrolases on bacteria. VIII. The combined effect of leukocyte extracts, lysozyme, enzyme "cocktails" and penicillin on the lysis of Staphylococcus aureus and group A streptococci in vitro. Inflammation. 1: 371-407.

30. Washington, J. A. II. 1979. The effects and significance of subminimal inhibitory concentrations of antibiotics. Rev. Infect. Dis. 1: 781-786.

31. Bryant, R. E., J. A. Wazza, and A. L. Rashad. 1978. Modification of antimicrobial activity by pus from patients with anaerobic infections. 18th ICAAC. Abstract 363.

32. Zak, O., and F. Kradolfer. 1979. Effects of subminimal inhibitory concentrations of antibiotics in experimental infections. Rev. Infect. Dis. 1: 862-879.

33. Shah, D. M., G. Heetclerks, and W. Stille. 1976. Activity of amikacin at subinhibitory levels. J. Antimicrob. Chemother. 2: 97-100.

34. Greenwood, D. 1976. Differentiation of mechanisms responsible for inoculum effects in the response of Escherichia coli to a variety of antibiotics. J. Antimicrob. Chemother. 2: 87-95.

35. Hakenbeck, R., S. Waks, and A. Tomasz. 1978. Characterization of cell wall polymers secreted into the growth medium of lysis-defective pneumococci during treatment with penicillin and other inhibitors of cell wall synthesis. Antimicrob. Agents Chemother. 13: 302-311.

36. Schlinder, C. A., and V. T. Schumardt. 1965. Purification and properties of lysostaphin, a lytic agent for Staphylococcus aureus. Biochem. Biophys. Acta 97: 242-250. 
37. Malawista, S. E., J. B. L. Gee, and K. G. Beusche. 1971. Cytochalasin B reversibly inhibits phagocytosis: functional, metabolic and ultrastructural effects in human blood leukocytes and rabbit alveolar macrophages. Yale J. Biol. Med. 44: 286-300.

38. Zigmond, S. H., and J. G. Hirsch. 1972. Effects of cytochalasin-B in polymorphonuclear leukocyte locomotion, phagocytosis and glycolysis. Exp. Cell Res. 73: 383-389.

39. Cook, F. V., Farrar, W. E. 1978. Vancomycin revisited. Ann. Intern. Med. 88: 813-818.

40. Hahn, F. E., and S. G. Sarre. 1969. Mechanisms of action of gentamicin. J. Infect. Dis. 119: 364-369.

41. Root, R. K., and J. A. Metcalf. 1979. Surface binding and enhanced killing of penicillin-treated $S$. aureus $502 \mathrm{~A}$ by human neutrophils: mechanisms of the effect. Clin. Res. 27: 480A. (Abstr.)

42. Isturiz, R. E., V. T. Andriole, and R. K. Root. 1979. Effects of subinhibitory concentrations of antibiotics on killing of $S$. aureus by human neutrophils. Clin. Res. 27: 347A. (Abstr.)

43. Isturiz, R. E., J. A. Metcalf, and R. K. Root. 1980. Augmented killing of streptococci by human neutrophils (PMNs) after penicillin pre-treatment. Clin. Res. 28: 512A. (Abstr.)

44. Yourtee, E. L., J. A. Metcalf, R. K. Root. 1980. Augmented killing of penicillin (PEN) pretreated $S$. aureus by human neutrophils (PMNs): role of complement. Clin. Res. 28: 383A. 